\title{
Impact of Corporate Sustainability on Firm Value: Indonesian Context
}

\author{
Muhammad Yusuf Shalihin \\ Faculty of Economics and Business \\ Universitas Padjadjaran \\ Harry Suharman \\ Faculty of Economics and Business \\ Universitas Padjadjaran \\ Dede Abdul Hasyir \\ Faculty of Economics and Business \\ Universitas Padjadjaran
}

\begin{abstract}
Sustainability reports emerge as a critical problem in the business world. Companies do not merely pursue profit maximization, but must pay attention to non-financial factors to maintain longterm growth. This study aims to investigate the relationship between company sustainability and company value. This study involved a sample of companies included in the proper index listed on the capital market and included in the category of 45 of the most actively traded companies (LQ45) on the Indonesia Stock Exchange with a study period of 2015-2018. Sample selection by purposive sampling method with the final results obtained 20 sample companies that meet the sample criteria. Then the data is tested with the Generalized Method of Moment (GMM) estimation model analysis method. The results of this study indicate that corporate sustainability has a positive effect on the value of marketbased companies. This research implies that companies and the Indonesian government must pay attention to increasing sustainability reporting. It is because proven to be used as a corporate strategy in improving long term performance and maximizing company value.
\end{abstract}

Keyword: PROPER; Environment; Indonesia; LQ45; Reporting

\section{Introduction}

This study investigates whether the capital market in Indonesia respects companies that practice corporate sustainability by using an appropriate index size as a measure of sustainability practices and Tobins $\mathrm{Q}$ as a measure for firm value variable. The definition of sustainability arises from the triple bottom line concept of economic, social, and environmental responsibility. In this definition, not only considers the physical environment and natural resource management issues but also in the economic and social context in business activities involving business system models, the dynamic act behavior is needed in the creation of corporate value for the long term (Yu \& Zhao, 2015).

Investors have begun to consider the factor of corporate sustainability in corporate investment criteria. Despite its development in various countries, countries in Europe and America generally dominate more than Asian countries (Welford, 2004). However, there is potential growth in the companies' sustainability practices in the Asian market because many investors are investing in the Asian market (Cheung, Tan, Ahn, \& Zhang, 2010). On the other hand, the majority of corporate executives in Asia do not consider social performance as a strategic component of financial performance (Lines, 2004). Investor's reaction to the companies sustainability performance could be part of crucial drivers for the development of corporate sustainability in Asia, especially Indonesia. Laskar \& Gopal Maji's research (2018) found evidence that the quality level of corporate sustainability disclosure in Indonesia is deficient compared to other Asian countries such as Japan, India, and South Korea. 
The performance of non-financial companies has begun to attract the attention of professional investors. They realize that the profitability aspect only is not sufficient for the companies long-term growth. When choosing from an economic, strategic, and operational perspective to consider environmental and social issues, sustainability reporting will help increase company transparency, strengthen risk management, encourage stakeholder involvement and improve communication with stakeholders (Loh, Thomas, \& Wang, 2017). Companies are generally considered to be more focused on profit maximization, while nonfinancial disclosures are not too contradictory. However, researchers have shown that there is a relationship between the disclosure of sustainability and firm value (Berthelot, Coulmont, \& Serret, 2012).

The primary purpose is to examine the market valuation of the companies sustainability performance, expressly, by exploring the relevance of sustainability performance concerning investor response in the Indonesian capital market. With the development of capital markets in Indonesia, the results of this study have implications for the practical interests of management, investors, and regulators in Indonesia. The results of this study are expected to motivate companies and the Indonesian government to increase awareness of corporate sustainability reporting.

The composition of this paper consists of research background, literature review, and hypothesis development that explains the framework of the relationship between corporate sustainability practices and firm value. Based on a literature review, we discuss theories and formulation of hypotheses. The next section describes data and methodology, followed by results and empirical analysis. For the last part, this study concludes and highlights the implications of the results and limitations of the study.

\section{Literature Review and Hypothesis Development}

Some of the results of empirical research provide evidence that sustainability reporting reduces information asymmetry between managers and investors that can increase the value of the company (Schadewitz \& Niskala, 2010) and company performance (Ameer \& Othman, 2012). The issue of disclosure related to company sustainability to stakeholders will increase corporate accountability and transparency so that it will assist investors in conducting evaluations appropriately (Nobanee \& Ellili, 2016). Besides, this report also provides added value in enhancing the company's image, strengthening public relations, and legitimizing company activities (Kilic, Kuzey, \& Uyar, 2015).

Theories relating to corporate sustainability reporting are agency, legitimacy, stakeholder and signaling theory Deegan (2002), Lourenço \& Branco (2013), Reverte (2009), Ruhnke \& Gabriel (2013), and Spence (2002). According to Cormier, Magnan, \& Van Velthoven (2005), the practice of reporting sustainability is a complex phenomenon. Fama \& Jensen (1983) states that agency costs arise due to conflicts of interest and information asymmetry between managers and owners. Therefore, sustainability reporting plays an essential role in reducing information asymmetry.

According to Deegan (2002), companies need to gain social legitimacy in running their business to obtain the resources needed to carry out their activities, so that sustainability reports are a tool to legitimize their business and show that companies can be accepted in the community. Berthelot et al. (2012) and Reverte (2009) said that in theory, stakeholder companies need to maintain good relations with stakeholders so they must fulfill the information they need through sustainability reports. Meanwhile, according to Ruhnke \& Gabriel (2013) and Spence (2002) said that in company signaling theory through sustainability reports sends messages about company performance, which includes economic, social, and environmental performance.

Several literature reviews have linked sustainability reports with corporate value in developed countries, especially Europe and America, but the results of the study are still controversial. Like the results of Lo \& Kwan (2017) study that investors are not concerned with environmental, social, and governance 
(ESG) initiatives. The study was conducted in Hong Kong in 2010-2012. It contradicts the results of the study of Loh et al. (2017) which revealed that the sustainability report is positively related to the market value of the company; the better the quality of reporting, the stronger the engagement. The study was conducted on company listings in Singapore in 2015. In line with Kuzey \& Uyar (2017) that sustainability reporting drives firm value.

On the other hand, the market did not respond positively because of the quality of the sustainability report. As has been proven by Guidry \& Patten (2010) that there is a problem in the quality of the report associated with market reactions. The results state that the market did not respond significantly when the company released its sustainability report. However, in the cross-section analysis, it was found that a more qualified sustainability report showed a more favorable market reaction than companies that issued the basic.

This result applies when entering control variables, namely company size, and membership in industries that already have a social reputation. This study was conducted on companies in the US with a measurement of the quality of disclosure of sustainability reports based on references from the Global Reporting Initiative. Legendre \& Coderre (2013) argued that there is often skepticism and mistrust of stakeholders and experts about CSR reports released by the company so that the contents of CSR reports are less attractive to stakeholders. In order to increase the report's credibility, CSR reports must use language that is easy to understand, based on truth (facts), sincere and specific to the information needed by stakeholders. Based on the literature review above, we formulated the following:

Hypothesis: Corporate sustainability has a positive effect on firm value.

\section{Data and Methodology}

The Ministry of Environment issues a proper index (company performance evaluation program) to give awards in the field of sustainability to companies in Indonesia. It is an effort to encourage companies to manage the environment through information instruments by actively involving the community. Because not all companies are given a rating by the proper listing index on the Indonesia Stock Exchange, we chose a sample based on the most actively traded listing company (LQ45). The reason we chose this sample was that the companies in the LQ45 category represented investors' interest in choosing stock investments and we assumed that the blue-chip company performed well and provided a complete report.

We chose a period of 2015-2018 because in 2015 , there was a change in the format of published reports from previous years, while in 2018 , the latest data was available. The sample was chosen based on the purposive sampling method with the following criteria: (1) listed in the LQ45 index in the period August 2018; (2) consistently registered in the proper index from 2015-2018; and (3) all the information we need in this study is available. The research data were obtained from the Indonesia Stock Exchange website (www.idx.co.id).

This study used the firm value as the dependent variable. The measurement of the dependent variable is Tobin's Q because this measure is market-based so it can reflect the company's value according to current conditions. Besides that, it has advantages compared to accounting-based performance because Tobin's Q ratio is not based on accounting profit, which is vulnerable to the practice of creative accounting techniques. Market value reflects the present value of future cash flows based on future information (Singh, Tabassum, Darwish, \& Batsakis, 2018). This measurement has also been used by previous researchers such as (Buallay, 2019; Nawaz, 2017; Saidat, Silva, \& Seaman, 2019; Shamsudin, Abdullah, \& Osman, 2018; Singh et al., 2018). The formula for calculating Tobin's Q ratio is the market value of equity + liabilities divided by the book value of total assets + liabilities (Singh et al., 2018).

The independent variable (variable $\mathrm{X}$ ) in this study is corporate sustainability. The measurement of the dependent variable, in this case, uses the proper index issued by the Ministry of Environment. This measurement has also been used in research (Rakhiemah \& Agustia, 2012). The proper index classifies five categories based on color. In this study, the score is given based on the highest performance 
of 5 or in gold and the lowest rank with a score of 1 or black. The following is an explanation of scores and ratings based on proper indexes:

Tabel 1. Company Performance Rating Program in Environmental Management

Rating Color Score Criteria

\begin{tabular}{llll}
\hline 1 & Gold & 5 & $\begin{array}{l}\text { Consistently demonstrates environmental excellence in the } \\
\text { production or service process and conducts business that is ethical } \\
\text { and responsible to society }\end{array}$ \\
2 Green 4 & $\begin{array}{l}\text { Conducting environmental management more than what is required } \\
\text { (beyond compliance) through an environmental management } \\
\text { system, utilizing resources efficiently and making reasonable social } \\
\text { responsibility efforts }\end{array}$
\end{tabular}

$\begin{array}{llll}3 & \text { Blue } & 3 & \text { Carry out environmental management efforts as required } \\ 4 & \text { Red } & 2 & \begin{array}{l}\text { Efforts to manage the environment are not following the } \\ \text { requirements }\end{array}\end{array}$

$5 \quad$ Black 1

Deliberately committed negligence resulting in environmental pollution or environmental damage and violates the required regulations and does not carry out administrative sanctions

Source: Indonesia`s Ministry of Environmental

This study uses panel data from 20142018 with a sample of companies included in the LQ45 index and PROPER ranking. The hypothesis test is conducted using a series of tests to determine the panel data model used.

F test that all $\mathrm{u}_{\mathrm{i}} \mathrm{i}=0: \mathrm{F}(19,57)=200.22 \quad$ Prob $>\mathrm{F}=0.0000$

Chow test results to determine the best model between OLS pools or fixed effects (redundant effects tests). The probability value of the chow test is 0.0000 , and the value is smaller than the
A significant level of 0.05 . Then it can be concluded that $\mathrm{HO}$ is rejected and $\mathrm{Ha}$ is accepted so that the model chosen according to the chow test is fixed effects.

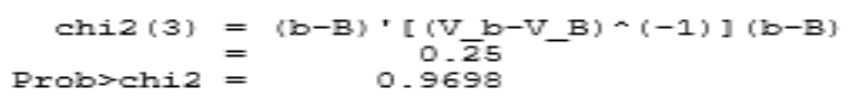

The next step is the Hausmann test. This test is to determine whether the model is more suitable to use between the Fixed Effect vs. Random Effect. Probability indicates a value of 0.9698 ; this value $>0.05$ so that the chosen model is a random effect. Based on the model selection test by comparing the Common Effect (Pooled OLS), Fixed Effect, and Random Effects Models, the selected model is the Random Effect model.
For control variables, the study refers to previous researchers (Saidat et al., 2019) with firm size and leverage. Firm size measurement by natural log of total assets, while leverage with the total debt formula divided by corporate assets. Based on the discussion, the estimation model developed to analyze the relationship between corporate sustainability and company value in this study is as follows: 
$\mathrm{FV}_{\mathrm{it}}=\beta_{0}+\beta_{1} \mathrm{CS}_{\mathrm{it}}+\beta_{2} \mathrm{SIZ}_{\mathrm{it}}+\beta_{3} \mathrm{LEV}_{\mathrm{it}}+\varepsilon_{\mathrm{it}}$, Which $\mathrm{FV}$ is firm value, CS is corporate sustainability, SIZ is company size and LEV is leverage. Then $\varepsilon$ is an error, and it shows the period of observation. Hypothesis testing is done by GMM estimation regarding previous studies (Tran \& Vo, 2018). Criteria for acceptance of hypotheses with a significance level of 5\% (Sekaran \& Bougie, 2010).

\section{Results and Discussion}

Based on the results of statistical data processing, it is obtained descriptive statistical results and hypothesis testing. Table 1 presents the descriptive statistical results, which are average, standard deviation, minimum, and maximum. Focusing on this research model that examines the effect of corporate sustainability (CS) with firm value (Q), it can be identified that overall the observed sample ranks 3.5. When viewed from this color category, it is included in the category of citizens between blue to green. It means that the average company included in the LQ45 index between 2015-2018 has carried out CS practices in the category of undertaking environmental management efforts as required by law.
Based on the minimum and maximum values, the companies in this study sample still have companies in the category of not trying to manage the environment according to the required standards. Some companies get a value of 2 , about the proper index ranking that value 2 is in the red color category. These companies include PT Adaro Energy Tbk in 2017-2018 and PT Sri Rejeki Isman Tbk in 2015-2016. While some companies that received the highest gold value or rank with a value of 5 . During the observation period from 2015-2018, there were three companies that always consistently obtained the gold category, namely PT Aneka Tambang Tbk, PT Medco Energi Internasional Tbk, and PT Bukit Asam Tbk.

Control variables for company specifics are size and leverage. Size value by looking at total assets, the highest was PT Indah Kiat Pulp \& Paper Tbk in 2018, and the lowest is PT Sawit Sumbermas Sarana Tbk in 2015. While in terms of leverage with total debt size, the company with the highest debt is PT Indofood in 2018, while the lowest debt is owned by PT. Kalbe Farma Tbk in 2017. The maximum value is 7.9847 and the minimum value is 6.4349 . It indicates that the inter-company risk of the sample companies does not show any significant diversity.

Table 2. Descriptive Statistics

\begin{tabular}{llllll}
\hline Variable & Obs & Mean & Std. Dev. & Min & Max \\
\hline Q & 80 & 2.2195 & 2.9909 & 0.3964 & 13.3924 \\
CS & 80 & 3.5000 & 0.8113 & 2.0000 & 5.0000 \\
SIZ & 80 & 7.5582 & 0.3180 & 6.8435 & 8.1029 \\
LEV & 80 & 7.1482 & 0.4092 & 6.4349 & 7.9847 \\
\hline
\end{tabular}

Before conducting a regression test, the classic assumption test is carried out to ensure that there are no problems in the classical assumption. Test for normality with the Kolmogorov-Smirnov model with a significance of 0.196 . Because the value is> 0.05 , then the data is normally distributed. Table 2 reports the results of the regression analysis based on market performance to measure firm value. This model examines the influence of CS with FV on companies included in the LQ45 index in the second semester of 2011.

CS was found to have a positive and significant relationship at the 0.05 significance level, so the main hypothesis in this study was accepted. It shows that corporate sustainability practices initiated by the Ministry of Environment through the proper index influence investors in investment decisions in the Indonesian capital market. However, all control variables have a negative and insignificant relationship at the 0.05 level of significance, which is proxied by total assets and leverage. Based on the $\mathrm{R}^{2}$ test obtained a value of 0.111 , this means that the variable $X$ affects the $\mathrm{Y}$ variable by $11 \%$, while other variables influence $89 \%$.

The results of this study are following previous studies conducted by Loh et al., (2017), Lo \& Kwan, (2017) and Kuzey \& Uyar, (2017), which document the positive 
relationship between corporate sustainability and firm value. This result supports signaling theory; namely, when a company gets a good rating in sustainability reporting, it will respond positively. In the context of Indonesia, investors still have confidence in the legitimacy of the proper index released by the Ministry of Environment to provide a positive response.

Table 3. Hypothesis Test Result

\begin{tabular}{llll}
\hline Variable & $\mathrm{N}$ & Coefficient & Probability \\
\hline CS & 80 & + & 0.024 \\
SIZ & 80 & - & 0.082 \\
LEV & 80 & - & 0.341 \\
\hline
\end{tabular}

The sample of companies taken in the study has considerable brand strength so that the public has high trust in every report published by the company. Besides, the companies in the sample also have good financial fundamentals in terms of profitability and leverage levels with good risk management. However, as a wise investor must remain careful in reading the publication report. Because according to Braam, Uit De Weerd, Hauck, \& Huijbregts, (2016) that companies that have weak environmental practices tend to disclose higher environmental information (overstatement), because of the company's desire to seek legitimacy.

Most companies in Indonesia adopt business operations from the western world. Thus, to maintain the company's competitive advantage on a global scale, companies in Indonesia need to integrate and communicate sustainability strategies in all business lines. The results of this study can motivate managers to incorporate CS strategies into the management process. This study contributes to the importance of sustainability, increasing government confidence in a company, and could increase compliance with applicable law.

\section{Conclusions and Suggestions}

This study examines the relationship between corporate sustainability and corporate value with market value-based measurements. This study uses company data that includes the LQ45 index. This study proves that corporate sustainability has a positive effect on the value of market-based companies. The results support the signaling theory that good corporate sustainability practices will respond positively to the market.
Corporate sustainability reporting can be used as a long-term corporate strategy to improve company performance and value. In this research, corporate sustainability is proven to increase company value. The results of this study imply that the companies in Indonesia should improve CS reporting practices. The results of this study also motivated corporate managers and the Indonesian government to raise awareness about the importance of corporate sustainability.

The limitation of this study is that this research does not look at the quality of sustainability reports, so it does not detect whether the reports released by each company have met the aspects that are easily understood, under the facts, contain all the information needed by stakeholders. Then the scope of the sample chosen is only limited to companies included in the LQ45 index assuming it has good financial fundamentals so that this can be biased. Then further research should examine all companies indexed as proper and listed on the stock exchange to reduce bias. Add other independent variables so that the relationship in this research model is stronger such as adding variables of the industry type, profitability, the concentration of ownership, and utilization of intellectual capital.

\section{References}

Ameer, R., \& Othman, R. (2012). Sustainability practices and corporate financial performance: A study based on the top global corporations. Journal of Business Ethics, $108(1), \quad 61-79$. https://doi.org/10.1007/s10551-0111063-y

Berthelot, S., Coulmont, M., \& Serret, V. (2012). Do Investors Value 
Sustainability Reports? A Canadian Study. Corporate Social Responsibility and Environmental Management, 19(6), 355-363. https://doi.org/10.1002/csr.285

Braam, G. J. M., Uit De Weerd, L., Hauck, M., \& Huijbregts, M. A. J. (2016). Determinants of corporate environmental reporting: The importance of environmental performance and assurance. Journal of Cleaner Production, 129, 724-734. https://doi.org/10.1016/j.jclepro.2016.03 .039

Buallay, A. (2019). Corporate governance, Sharia'ah governance, and performance: A cross-country comparison in MENA region. International Journal of Islamic and Middle Eastern Finance and Management, 12(2), 216-235. https://doi.org/10.1108/IMEFM-072017-0172

Cheung, Y. L., Tan, W., Ahn, H. J., \& Zhang, Z. (2010). Does corporate social responsibility matter in Asian Emerging Markets? Journal of Business Ethics, 92(3), 401-413. https://doi.org/10.1007/s10551-0090164-3

Cormier, D., Magnan, M., \& Van Velthoven, B. (2005). Environmental disclosure quality in large German companies: Economic incentives, public pressures or institutional conditions? European Accounting Review, 14(1), 3-39. https://doi.org/10.1080/0963818042000 339617

Deegan, C. (2002). Introduction: The legitimising effect of social and environmental disclosures - a theoretical foundation. Accounting, Auditing \& Accountability Journal, 15(3), 282-311. https://doi.org/10.1108/0951357021043 5852

Fama, E. F., \& Jensen, M. C. (1983). Separation of ownership and control. Journal Law Economy, 26(2), 301-325.

Guidry, R. P., \& Patten, D. M. (2010). Market reactions to the first-time issuance of corporate sustainability reports: Evidence that quality matters. Sustainability Accounting, Management and Policy Journal, 1(1), 33-50. https://doi.org/10.1108/2040802101105 9214

Kilic, M., Kuzey, C., \& Uyar, A. (2015). The impact of ownership and board structure on corporate social responsibility (CSR) reporting in the Turkish banking industry. Corporate Governance International Journal of Business in Society, 15(3), 357-374. https://doi.org/10.1108/CG-02-20140022

Kuzey, C., \& Uyar, A. (2017). Determinants of sustainability reporting and its impact on firm value: Evidence from the emerging market of Turkey. Journal of Cleaner Production, 143, 27-39. https://doi.org/10.1016/j.jclepro.2016.12 .153

Laskar, N., \& Gopal Maji, S. (2018). Disclosure of corporate sustainability performance and firm performance in Asia. Asian Review of Accounting (Vol. 26). https://doi.org/10.1108/ARA-022017-0029

Legendre, S., \& Coderre, F. (2013). Determinants of GRI G3 Application Levels: The Case of the Fortune Global 500. Corporate Social Responsibility and Environmental Management, 20(3), 182-192. https://doi.org/10.1002/csr.1285

Lines, V. L. (2004). Corporate reputation in Asia: Looking beyond bottom-line performance. Journal of Communication Management, 8(3), 233-245. https://doi.org/10.1108/1363254041080 7664

Lo, K. Y., \& Kwan, C. L. (2017). The Effect of Environmental, Social, Governance and Sustainability Initiatives on Stock Value - Examining Market Response to Initiatives Undertaken by Listed Companies. Corporate Social Responsibility and Environmental 
Management, 24(6), 606-619. https://doi.org/10.1002/csr.1431

Loh, L., Thomas, T., \& Wang, Y. (2017). Sustainability reporting and firm value: Evidence from Singapore-listed companies. Sustainability (Switzerland), 9(11), 1-12. https://doi.org/10.3390/su9112112

Lourenço, I. C., \& Branco, M. C. (2013). Determinants of corporate sustainability performance in emerging markets: The Brazilian case. Journal of Cleaner Production, 57, 134-141. https://doi.org/10.1016/j.jclepro.2013.06 .013

Nawaz, T. (2017). Intellectual capital, financial crisis and performance of Islamic banks: Does Shariah governance matter? International Journal of Business and Society, 18(1), 211-226.

Nobanee, H., \& Ellili, N. (2016). Corporate sustainability disclosure in annual reports: Evidence from UAE banks: Islamic versus conventional. Renewable and Sustainable Energy Reviews, 55, 1336-1341. https://doi.org/10.1016/j.rser.2015.07.08 4

Reverte, C. (2009). Determinants of corporate social responsibility disclosure ratings by Spanish listed firms. Journal of Business Ethics, 88(2), 351-366. https://doi.org/10.1007/s10551-0089968-9

Ruhnke, K., \& Gabriel, A. (2013). Determinants of voluntary assurance on sustainability reports: an empirical analysis. Journal of Business Economics, 83(9), 1063-1091. https://doi.org/10.1007/s1 1573-0130686-0

Saidat, Z., Silva, M., \& Seaman, C. (2019). The relationship between corporate governance and financial performance: Evidence from Jordanian family and nonfamily firms. Journal of Family Business Management, 9(1), 54-78.
https://doi.org/10.1108/JFBM-11-20170036

Schadewitz, H., \& Niskala, M. (2010). Communication via responsibility reporting and its effect on firm value in Finland. Corporate Social Responsibility and Environmental Management, 17(2), 96-106. https://doi.org/10.1002/csr.234

Sekaran, U., \& Bougie, R. (2010). Research Methods for Business: a Skill Building Approach (5th Ed.). Wiley.

Shamsudin, S. M., Abdullah, W. R. W., \& Osman, A. H. (2018). Corporate Governance Practices and Firm Performance After Revised Code of Corporate Governance: Evidence from Malaysia. State-of-the-Art Theories and Empirical Evidence, 49-63. https://doi.org/10.1007/978-981-106926-0_4

Singh, S., Tabassum, N., Darwish, T. K., \& Batsakis, G. (2018). Corporate Governance and Tobin's $\mathrm{Q}$ as a Measure of Organizational Performance. British Journal of Management, 29(1), 171-190. https://doi.org/10.1111/14678551.12237

Spence, M. (2002). Signaling in retrospect and the informational structure of markets. American Economic Review, 92(3), 434459.

https://doi.org/10.1257/0002828026013 6200

Tran, D. B., \& Vo, D. H. (2018). Should bankers be concerned with Intellectual capital? A study of the Thai banking sector. Journal of Intellectual Capital, 19(5), 897-914. https://doi.org/10.1108/JIC-12-20170185

Welford, R. (2004). Corporate Social Responsibility in Europe and Asia: Critical Elements and Best Practice. The Journal of Corporate Citizenship, 13, 31-47.

Yu, M., \& Zhao, R. (2015). Sustainability and firm valuation: an international 
investigation. International Journal of Accounting and Information Management, 23(3), 289-307.
https://doi.org/10.1108/IJAIM-07-20140050 